INDEPENDENT JOURNAL OF MANAGEMENT \& PRODUCTION (IJM\&P)

http://www.ijmp.jor.br

v. 12, n. 4, May-June 2021

ISSN: 2236-269X

DOI: 10.14807/ijmp.v12i4.1336

\title{
IMPACT OF ELECTRONIC WORD OF MOUTH TO THE PURCHASE INTENTION - THE CASE OF INSTAGRAM
}

\author{
Vi Truc Ho \\ Industrial University of Ho Chi Minh City, Viet Nam \\ E-mail: hotrucvi@iuh.edu.vn
}

Nhan Trong Phan Industrial University of Ho Chi Minh City, Viet Nam

E-mail: phantrongnhan@iuh.edu.vn

Phuong Viet Le-Hoang Industrial University of Ho Chi Minh City, Viet Nam E-mail: lehoangvietphuong@iuh.edu.vn

Submission: 4/24/2020

Revision: 6/3/2020

Accept: 7/27/2020

\section{ABSTRACT}

This research aims to discover and confirm the factors of e-WOM that influence users' shopping intentions on Instagram. The data was collected from 700 customers who belong to Gen Y and Gen Z from 18 to 39 years old who live and work in Vietnam. The research model and the scales were built from the empirical research of e-WOM from Lim (2016); Park et al. (2007); Prendergast et al. (2010). Quantitative methods were performed by Cronbach's Alpha reliability testing, EFA discovery factor analysis, regression, and ANOVA test. The research results showed that the fourth factor of e-WOM positively impacts users' purchase intent on Instagram with decreasing levels as Information Provider's Expertise, the quantity of e-WOM, and the Source credibility of eWOM, and the quality of e-WOM, respectively. Also, users' purchase intention on Instagram under the impact of e-WOM varies by gender, but there is no difference by age and income.

Keywords: E-WOM; Gen Y; Gen Z; Instagram; Purchase intention, Vietnam 
ISSN: $2236-269 X$

DOI: $10.14807 /$ ijmp.v12i4.1336

\section{INTRODUCTION}

Instagram is one of the most attractive social media sites today. By the end of 2019, Instagram has grown to 1 billion users, and more than 4 billion likes per day on Instagram (Clement, 2019). In particular, each image posted on the platform has an average interaction rate of 23\% higher than Facebook. In Vietnam, as of the end of January 2019, people using Instagram social network account for a significant number (6.2 million), ranking second after Facebook with nearly 61 million users (Kemp, 2019).

The most striking feature of Instagram right now is the new IGTV video platform) which was announced and launched in June 2018. Unlike YouTube and other video streaming platforms, IGTV is dedicated to streaming videos according to vertically, which fits well for mobile devices. Besides, with the store on Instagram, shopping becomes more comfortable. With just one click, customers can go directly to the product page and add to their shopping cart.

According to Statusbrew (2019), Instagram stories have grown from 150 million to 500 million daily active viewers, which is why it is considered the rising social media stars. In particular, the interaction with brands on Instagram is ten times higher than Facebook, 54 times higher than Pinterest, and 84 times higher than Twitter (Statusbrew, 2019). With the outstanding features of Instagram, it is strongly believed that social network has been growing sharply in the future.

With the development of the Internet and social networking platforms such as Facebook, Instagram, Youtube ..., before shopping, consumers can exchange information, advice, or receive advice from many different sources. According to Chatterjee (2001), the Internet helps increase the amount of word of mouth information, or more specifically, consumers can search for information from other marketers or consumers about the products or services they attend to buy.

Accordingly, Hennig-Thurau et al. (2004) confirmed that discussions related to brands or products and services of brands in an online environment are called word of mouth (eWOM). Many customers often look for information verified by experienced people, making them more comfortable making purchase decisions (Pitta \& Fowler, 2005).

According to Nielsen (2012), 92\% of consumers worldwide believe in viral media, such as word-of-mouth and recommendations from friends and family over all other types of advertising, and have $40 \%$ of people bought something after watching recommendations on Instagram, Youtube (Knightley, 2018). Besides, eWOM can reach a large number of customers 
DOI: 10.14807/ijmp.v12i4.1336

because the message can be sent to millions of users via the Internet at the same time (Cakim, 2009; Filieri \& McLeay, 2014; Liu, 2006), and it spread over a short period (Huang et al., 2011).

On the contrary, negative comments can also spread quickly in the online environment to many customers, thereby negatively affecting the company's reputation. Therefore, understanding the impact of eWOM on a user's social media buying intent is an aspect that needs to be studied as it helps marketers create engaging advertising activities, attract potential customers, especially Instagram - a social network that has grown in recent years with outstanding features with a tremendous competitive advantage.

\section{LITERATURE REVIEW}

Electronic word of mouth (eWOM) is defined as any positive or negative statement that comes from customers (including potential customer, current customers) about the product or company which passed on to people and organizations via the Internet (Hennig-Thurau et al., 2004). Primarily, eWOM is also known as "Internet WOM" (Goldenberg et al., 2001) or "Buzz Marketing" (Thomas, 2004).

Ratings and reviews are two common forms of eWOM (Chatterjee, 2001) that are assessed by consumers or experts (Chen \& Xie, 2004). With the different characteristics of the online platform, there are different forms of eWOM, such as one-to-one (email), one-to-many (web-site), and among many people (blog) (Litvin et al., 2008). According to Moran and Muzellec (2014), the customer applies eWOM to discuss ideas and share their experiences with acquaintances on social networks.

Purchase intention is a reliable measure of actual buying behavior, which refers to the customer's tendency to purchase products or services (Kalwani and Silk, 1982). Several factors influence consumer purchasing intent, which previous studies have found, such as information quality (Park et al., 2007; Lee \& Shin, 2014) and information reliability (Prendergast et al. , 2010). To be more specific, the higher the quality of information and the reliability of the message, the more consumers' buying intention (Lee \& Shin, 2014; Park et al., 2007; Prendergast et al. , 2010;).

EWOM has a positive influence on purchasing intent (Bickart and Schindler, 2001; Park et al., 2007; Huang et al., 2011). A pioneer in the research of eWOM, Bickart, and Schindler (2001) found eWOM information from the customer rather than eWOM information from marketers on purchasing intention and be more reliable. 
INDEPENDENT JOURNAL OF MANAGEMENT \& PRODUCTION (IJM\&P)

http://www.ijmp.jor.br

v. 12, n. 4, May-June 2021

ISSN: 2236-269X

DOI: 10.14807/ijmp.v12i4.1336

Besides, Wang et al. (2012) also asserted that eWOM on social networks had a positive influence on purchase intent. In studying Lin et al. (2013), the authors demonstrated three main components of eWOM: eWOM quality, the number of eWOM, and the information provider's expertise. These components also received the approval of Lim (2016) when analyzing the impact of word-of-mouth on purchase intent and the willingness to pay for travel-related products. Another study by Erkan (2016), when combining the information adoption model (IAM), the authors focused on eWOM on three components, consist of the quality of eWOM, the number of eWOM, and the reliability of eWOM to consider its impact on customers' buying intention.

\section{HYPOTHESES DEVELOPMENT}

\subsection{The quality of e-WOM}

The quality of e-WOM is related to the persuasive power of the message (Bhattacherjee and Sanford, 2006). It is considered as an essential factor (DeLone and McLean, 1992). The quality of e-WOM is reviewed under the same content as the e-WOM information is detailed; provided by a reliable source; supported the point of view (Lin et al., 2013; Lim, 2016; Park et al., 2007); easy to understand (Lin et al., 2013); personalization (DeLone \& McLean; 1992). Research results show that consumers appreciate the quality of information, the more satisfied they are (Cheung \& Thadani, 2012; Sussman \& Siegal, 2003). Simultaneously, online reviews' quality has a positive influence on purchase intent (Lee \& Shin, 2014; Park et al., 2007; Lim, 2016). So, the hypothesis is as follows:

- H1: The quality of e-WOM positively affects consumers' purchase intention.

\subsection{The number of e-WOM}

The number of e-WOM is defined as the total number of comments via the online environment, and itself makes the comments more diverse (Cheung \& Thadani, 2012). There is a large number of e-WOM on the product, showing its popularity (Chatterjee, 2001; Chen \& Xie, 2004; Lim, 2016). In this study, the author uses the number of the e-WOM scale of Lim (2016) with the following principal contents: the popularity of the product, helping to make better decisions accordingly, the specific product has a good reputation. Also, having many reviewers review the product means that the product has good sales. Reading many other people's reviews can reduce consumers' anxiety because they believe that many others have also purchased them (Chatterjee, 2001). Therefore, this study suggests a hypothesis:

- H2: The number of e-WOM positively affects consumers' purchase intention. 
INDEPENDENT JOURNAL OF MANAGEMENT \& PRODUCTION (IJM\&P)

http://www.ijmp.jor.br

v. 12, n. 4, May-June 2021

ISSN: 2236-269X

DOI: $10.14807 /$ ijmp.v12i4.1336

\subsection{Source credibility of e-WOM}

Source credibility of e-WOM refers to the recipient's perception of the message's trustworthiness, not the message itself (Chaiken, 1980; Petty \& Cacioppo, 1986). According to Cheung et al. (2008), people are entitled to express their feelings about specific products or services without revealing their true identities in an online environment. Therefore, the reliability of different opinions depends on how users identify and feel. For the factor the credibility of e-WOM, the study uses four observed variables from the study of Prendergast et al. (2010), including message recipients who find those sources of information to be authentic, accurate, reliable, and persuasive. Many studies have shown the positive influence of information reliability on consumers' buying intentions (Park et al., 2007; Prendergast et al., 2010; Awad \& Ragowsky, 2008). Therefore, the hypothesis is as follows:

- H3: Source credibility of e-WOM positively affects consumers' purchase intention.

\subsection{Information Provider's Expertise}

Bloch and Richins (1986) discovered that users with product knowledge and experience could quickly and accurately evaluate. It increases the flow of information seeking by consumers who are not familiar with the product. Moreover, Gilly et al. (1998) find that the Information Provider's Expertise positively influences the consumer's purchase intention. These sources have an essential influence on changing consumers' attitudes and attitudes (Hovland \& Weiss, 1951). Lim (2016) added that providing the essential things that users have not considered and given me ideas that are different from other people's opinions is also crucial in customer decisions. Therefore, this study suggests a hypothesis:

- H4: Information Provider's Expertise positively affects consumers' purchase intention.

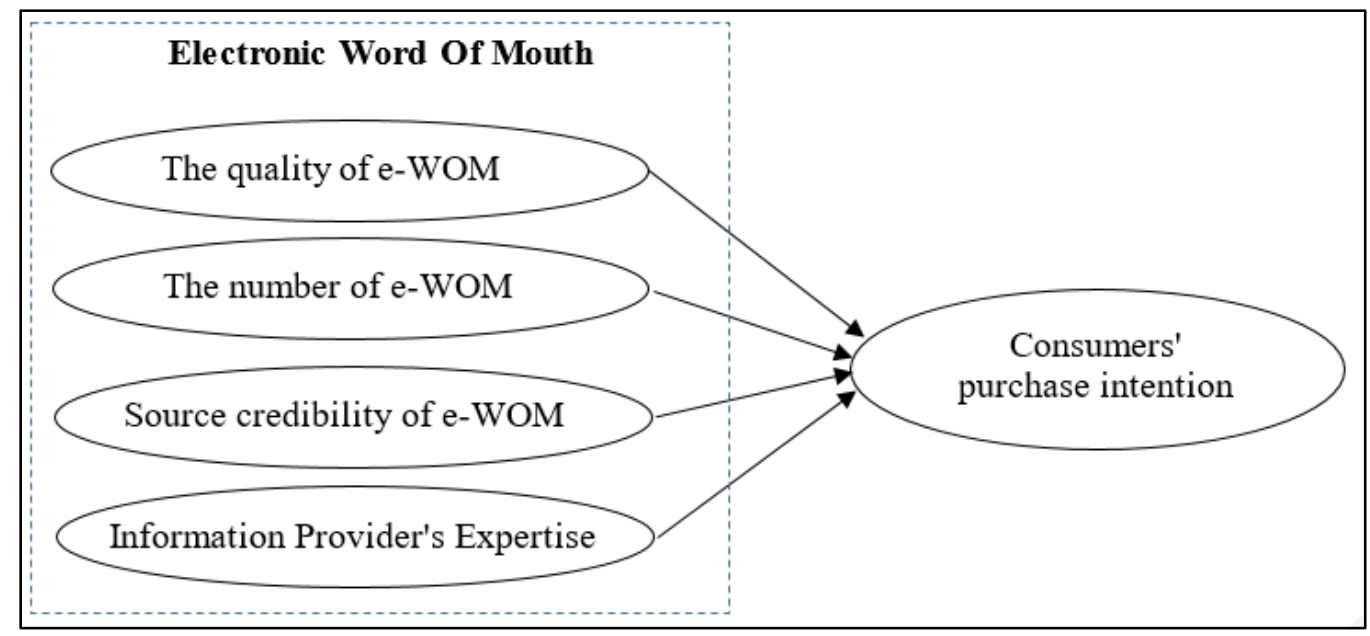

Figure 1: Proposed research model 
INDEPENDENT JOURNAL OF MANAGEMENT \& PRODUCTION (IJM\&P)

http://www.ijmp.jor.br

v. 12, n. 4, May-June 2021

ISSN: 2236-269X

DOI: 10.14807/ijmp.v12i4.1336

\section{METHODOLOGY}

The authors use a mixed-method, including a qualitative research method and quantitative research methods. The qualitative research method explores the scale by discussing hands-on with ten people using Instagram. Through hand-to-hand discussions, the scale is modified to suit the Instagram environment and ensure the intelligibility of the scales for users to conduct the survey smoothly. The quantitative research method was then conducted via an online questionnaire using Google Form using a convenient sampling method for Instagram users to test the proposed scale and theoretical model.

Besides, in order for the collected data to be valid, the number of sample surveys is also considered. The minimum sample size required by EFA is five times the total number of observed variables (Hair et al., 1998), and the minimum sample size for regression analysis is eight times the number of independent variables plus 50 (Tabachnick et al., 1996).

In this study, the total number of observed variables is 20, and the total number of independent variables is 4, so the minimum number of samples for EFA is 100, and for regression analysis is 82 . In summary, the minimum sample size to be achieved in the study is 100. However, to ensure the optimal amount of feedback and meet the minimum sample size conditions and the best cover results, the author decided to survey over 800 samples via Instagram. The results obtained the total number of samples collected was 700 samples, all of which are valid for analysis.

The Likert scale consists of 5 levels selected for the survey from 1 - Strongly disagree to 5 - Totally agree to collect results. Data analysis methods in this study include descriptive statistics, reliability assessment through Cronbach's Alpha coefficients, EFA method, and regression analysis to consumer buying intent by SPSS 20.0.

\section{DATA ANALYSIS AND RESULTS}

\subsection{Data description}

Table 1: Sample characteristics

\begin{tabular}{|c|l|r|r|}
\hline Groups & \multicolumn{1}{|c|}{ Characteristics } & Frequency & \multicolumn{1}{|c|}{ Percent } \\
\hline \multirow{2}{*}{ Gender } & Male & 320 & $45.71 \%$ \\
\cline { 2 - 4 } & Female & 380 & $54.29 \%$ \\
\hline \multirow{3}{*}{ Age } & $18-24$ & 282 & $40.29 \%$ \\
\cline { 2 - 4 } & $25-32$ & 281 & $40.14 \%$ \\
\cline { 2 - 4 } & $32-39$ & 137 & $19.57 \%$ \\
\hline \multirow{3}{*}{ Income } & $<5$ million VND & 119 & $17.00 \%$ \\
\cline { 2 - 4 } & $5-<10$ million VND & 278 & $39.71 \%$ \\
\cline { 2 - 5 } & $10-15$ million VND & 228 & $32.57 \%$ \\
\cline { 2 - 5 } & $>15$ million VND & 75 & $10.71 \%$ \\
\hline
\end{tabular}




\section{INDEPENDENT JOURNAL OF MANAGEMENT \& PRODUCTION (IJM\&P)}

http://www.ijmp.jor.br

v. 12, n. 4, May-June 2021

ISSN: 2236-269X

DOI: $10.14807 /$ ijmp.v12i4.1336

According to the survey data analysis, in 700 research samples collected, we found that the gender ratio using Instagram is not too different between males and females. The age group, 18-24 years old, accounted for the similar highest proportion with $40.29 \%$, followed by the age group of 25-32 years (40.14\%), and the lowest proportion was 32-39 years old (accounting for only 19.57\%). Besides, the highest ratio in income is a group from VND 5 million to under VND 10 million (reaching 39.71\%), and the first runner up is VND 10 million to VND 15 million (accounting for 32.57\%), while the income of less than VND 5 million and over VND 15 million is still available but at a lower rate (17\% and $10.71 \%$, respectively).

\subsection{Cronbach's Alpha Analysis Results}

Table 2: The Cronbach’s Alpha Results

\begin{tabular}{|c|c|c|c|}
\hline Items & Constructs & $\begin{array}{c}\text { Corrected } \\
\text { Item-Total } \\
\text { Correlation }\end{array}$ & $\begin{array}{c}\text { Cronbach's } \\
\text { Alpha if Item } \\
\text { Deleted }\end{array}$ \\
\hline \multicolumn{4}{|c|}{ The quality of e-WOM (Cronbach's Alpha = 0.795) } \\
\hline QL01 & Reviews posted on Instagram are clear & .597 & .749 \\
\hline QL02 & Reviews posted are understandable. & .617 & .739 \\
\hline QL03 & Reviews posted are objective. & .605 & .745 \\
\hline QL04 & Reviews posted are enough to support the point. & .605 & .745 \\
\hline \multicolumn{4}{|c|}{ The quantity of e-WOM (Cronbach's Alpha = 0.764) } \\
\hline QN01 & There are many reviews, inferring popular products. & .546 & .718 \\
\hline QN02 & $\begin{array}{l}\text { The number of reviews posted, suggesting the product } \\
\text { has good sales. }\end{array}$ & .612 & .681 \\
\hline QN03 & $\begin{array}{l}\text { High ratings and recommendations, the product has a } \\
\text { good reputation. }\end{array}$ & .553 & .713 \\
\hline QN04 & $\begin{array}{l}\text { The amount of review information posted helps me } \\
\text { make the right decision. }\end{array}$ & .544 & .718 \\
\hline \multicolumn{4}{|c|}{ Source credibility of e-WOM (Cronbach’s Alpha = .819) } \\
\hline SC01 & I think product reviews posted are convincing. & .663 & .762 \\
\hline SC02 & I think product reviews are authentic. & .676 & .758 \\
\hline SC03 & I think product reviews are credible. & .633 & .776 \\
\hline SC04 & I think the product reviews are accurate & .597 & .794 \\
\hline \multicolumn{4}{|c|}{ Information Provider's Expertise (Cronbach’s Alpha = .788) } \\
\hline IP01 & The person I follow has experience using the product. & .604 & .731 \\
\hline IP02 & The person I follow has a lot of product knowledge. & .596 & .735 \\
\hline IP03 & The person I follow can evaluate the product. & .613 & .728 \\
\hline IP04 & $\begin{array}{l}\text { The person I follow mentions things that I have not } \\
\text { considered yet. }\end{array}$ & .570 & .748 \\
\hline \multicolumn{4}{|c|}{ Purchase intention (Cronbach’s Alpha = .799) } \\
\hline IT01 & $\begin{array}{l}\text { After reviewing the review posted, I will buy the product } \\
\text { on Instagram }\end{array}$ & .647 & .722 \\
\hline IT02 & $\begin{array}{l}\text { After reviewing the reviews posted, I will buy the product } \\
\text { if I need it next time. }\end{array}$ & .623 & .748 \\
\hline IT03 & $\begin{array}{l}\text { After reviewing the reviews posted, I'm sure to buy the } \\
\text { product. }\end{array}$ & .661 & .708 \\
\hline
\end{tabular}


INDEPENDENT JOURNAL OF MANAGEMENT \& PRODUCTION (IJM\&P)

http://www.ijmp.jor.br

v. 12, n. 4, May-June 2021

ISSN: 2236-269X

DOI: 10.14807/ijmp.v12i4.1336

The results of Cronbach Alpha reliability coefficient analysis for all the remaining observed variables of the scales all ensure reliability conditions (Corrected Item is more significant than 0.5 , and Cronbach's Alpha is greater than 0.7 ), so all are retained to perform testing for the next step.

\subsection{Exploratory Factor Analysis (EFA) of Independent variables}

This paper uses the principal method of Principal Component Analysis, and the most commonly used rotation is Varimax. Bartlett test results have $\mathrm{KMO}=.826>0.5$, and sig $=$ 0.00, all variables are correlated with each component. The Total Variance Explained method at Eigenvalues values $=1.495>1$ and the Cumulative $\%=63.526 \%>50 \%$, satisfies the condition (Gerbing \& Anderson, 1988). The rotation matrix in EFA shows that factor loading is higher than 0.5 , divided into four components from 16 observed variables described in detail in the table:

Table 3: Rotated matrix of Independent variables

\begin{tabular}{|c|c|c|c|c|c|}
\hline \multirow{2}{*}{ Concepts } & \multirow{2}{*}{ Items } & \multicolumn{4}{|c|}{ Component } \\
\hline & & 1 & 2 & 3 & 4 \\
\hline \multirow{4}{*}{ Information Provider's Expertise } & IP02 & .777 & & & \\
\hline & IP03 & .765 & & & \\
\hline & IP04 & .739 & & & \\
\hline & IP01 & .728 & & & \\
\hline \multirow{4}{*}{ The quality of e-WOM } & QL03 & & .797 & & \\
\hline & QL02 & & .777 & & \\
\hline & QL04 & & .742 & & \\
\hline & QL01 & & .741 & & \\
\hline \multirow{4}{*}{ Source credibility of e-WOM } & SC01 & & & .811 & \\
\hline & SC02 & & & .809 & \\
\hline & SC03 & & & .803 & \\
\hline & SC04 & & & .591 & \\
\hline \multirow{4}{*}{ The quantity of e-WOM } & QN03 & & & & .768 \\
\hline & QN04 & & & & .761 \\
\hline & QN02 & & & & .728 \\
\hline & QN01 & & & & .682 \\
\hline \multicolumn{2}{|l|}{ KMO } & \multicolumn{4}{|c|}{$.826($ sig $=0.000)$} \\
\hline \multicolumn{2}{|l|}{ Eigenvalues } & \multicolumn{4}{|c|}{1.495} \\
\hline \multicolumn{2}{|l|}{ Total Variance Explained } & \multicolumn{4}{|c|}{$63.526 \%$} \\
\hline
\end{tabular}

\subsection{Exploratory Factor Analysis (EFA) of dependent variables}

The results of analysis are $\mathrm{KMO}=.709>0.5$ with sig $=0.00$, Eigenvalues $=2.141$ and Total Variance Explained $=71.365 \%>50 \%$, so all variables are correlated with each other. The detail result as followed: 
INDEPENDENT JOURNAL OF MANAGEMENT \& PRODUCTION (IJM\&P)

http://www.ijmp.jor.br

v. 12, n. 4, May-June 2021

ISSN: 2236-269X

DOI: 10.14807/ijmp.v12i4.1336

Table 4: Rotated matrix of dependent variables

\begin{tabular}{|l|l|l|}
\hline \multicolumn{1}{|c|}{ Concepts } & \multicolumn{1}{|c|}{ Items } & \multicolumn{1}{c|}{ Component } \\
\hline \multirow{3}{*}{ Purchase intention } & IT03 & .856 \\
\cline { 2 - 3 } & IT01 & .847 \\
\cline { 2 - 3 } & IT02 & .831 \\
\hline KMO & $0.709(\mathrm{sig}=0.000)$ \\
\hline \multicolumn{2}{|l|}{ Eigenvalues } & 2.141 \\
\hline \multicolumn{2}{|l|}{ Total Variance Explained } & $71.365 \%$ \\
\hline
\end{tabular}

\subsection{Regression analysis results}

According to the multivariate regression analysis results, the adjusted R2 coefficient is .532, which means that $53.2 \%$ of the intention variation is explained by the linear relationship between the research concepts related to e-WOM. At the same time, the VIF of each factor is small and less than 10; it shows no multicollinearity in the regression model. All the other coefficients in the regression model above are positive and Sig $<0.05$ (accept the hypothesis), meaning that the remaining three factors positively affect the purchase intention of the customer.

Table 5: Regression analysis results

\begin{tabular}{|c|c|c|c|c|c|c|c|}
\hline \multirow[b]{2}{*}{ Model } & \multicolumn{2}{|c|}{$\begin{array}{l}\text { Unstandardized } \\
\text { Coefficients }\end{array}$} & \multirow{2}{*}{$\begin{array}{c}\begin{array}{c}\text { Standardized } \\
\text { Coefficients }\end{array} \\
\text { Beta } \\
\end{array}$} & \multirow[b]{2}{*}{$\mathbf{t}$} & \multirow[b]{2}{*}{ Sig. } & \multicolumn{2}{|c|}{ Collinearity } \\
\hline & Beta & Sd. Error & & & & Tolerance & VIF \\
\hline (Constant) & -.171 & .153 & & -1.119 & .263 & & \\
\hline QN & .287 & .030 & .280 & 9.655 & .000 & .796 & 1.256 \\
\hline QL & .092 & .028 & .092 & 3.242 & .001 & .824 & 1.213 \\
\hline SC & .236 & .029 & .244 & 8.027 & .000 & .726 & 1.378 \\
\hline IP & .440 & .033 & .383 & 13.353 & .000 & .814 & 1.228 \\
\hline \multicolumn{3}{|c|}{ Adjusted $\mathrm{R}^{2}$} & \multicolumn{5}{|c|}{0.532} \\
\hline \multicolumn{3}{|c|}{ Sig. } & \multicolumn{5}{|c|}{0.000} \\
\hline \multicolumn{3}{|c|}{ Durbin Watson } & \multicolumn{5}{|c|}{1.681} \\
\hline
\end{tabular}

The standardized coefficients function is:

$$
\mathrm{IT}=0.383 \mathrm{IP}+0.280 \mathrm{QN}+0.244 \mathrm{SC}+0.092 \mathrm{QL}
$$

In particular, Information Provider's Expertise scale has the strongest impact on purchase intention $(\beta=0.383)$, followed by the quantity of e-WOM $(\beta=0.280)$ and Source credibility of e-WOM $(\beta=0.244)$, finally the quality of e-WOM scale has a lowest impact ( $\beta$ $=0.092)$.

\subsection{Hypothesis testing result}

Table 6: Hypothesis testing result

\begin{tabular}{|c|l|c|c|}
\hline Hypothesis & \multicolumn{1}{|c|}{ Content } & Relationship & Result \\
\hline H1 & $\begin{array}{l}\text { The quality of e-WOM } \rightarrow \text { consumers' purchase } \\
\text { intention }\end{array}$ & Positive & Accepted \\
\hline
\end{tabular}


INDEPENDENT JOURNAL OF MANAGEMENT \& PRODUCTION (IJM\&P)

http://www.ijmp.jor.br

v. 12, n. 4, May-June 2021

ISSN: 2236-269X

DOI: 10.14807/ijmp.v12i4.1336

\begin{tabular}{|c|l|c|c|} 
H2 & $\begin{array}{l}\text { The number of e-WOM } \rightarrow \text { consumers' purchase } \\
\text { intention. }\end{array}$ & Positive & Accepted \\
\hline H3 & $\begin{array}{l}\text { Source credibility of e-WOM } \rightarrow \text { consumers' } \\
\text { purchase intention }\end{array}$ & Positive & Accepted \\
\hline H4 & $\begin{array}{l}\text { Information Provider's Expertise } \rightarrow \text { consumers' } \\
\text { purchase intention }\end{array}$ & Positive & Accepted \\
\hline
\end{tabular}

\subsection{Examining differences in demographic characteristics to purchase intention}

\subsubsection{Gender}

- H5: There is no difference in the impact of e-WOM on the purchase intention of Instagram social network users who have different gender.

Table 7: Test the difference between gender and purchase intention

\begin{tabular}{|c|c|c|c|c|c|}
\hline \multicolumn{6}{|c|}{ Test of Homogeneity of Variances } \\
\hline \multicolumn{6}{|l|}{ Purchase Intention } \\
\hline Levene Statistic & \multicolumn{2}{|l|}{ df1 } & \multicolumn{2}{|l|}{$\mathrm{df} 2$} & Sig. \\
\hline 3.501 & & 3 & & 696 & .015 \\
\hline \multicolumn{6}{|c|}{ ANOVA } \\
\hline \multicolumn{6}{|l|}{ Purchase Intention } \\
\hline & Sum of Squares & $\mathrm{df}$ & Mean Square & $\mathrm{F}$ & Sig. \\
\hline Between Groups & 6.143 & 3 & 2.048 & 4.187 & .006 \\
\hline Within Groups & 340.377 & 696 & .489 & & \\
\hline Total & 346.520 & 699 & & & \\
\hline
\end{tabular}

According to tests of homogeneity of Variances, the result has sig. $=.015>0.05$, thus concluding the variance between the groups did not differ, meet the requirement to analyze ANOVA. The ANOVA test results show that the Sig $=0.006<0.05$, the hypothesis $(\mathrm{H} 5)$ is rejected. That means a difference in satisfaction in gender.

\subsubsection{Age}

- H6: There is no difference in the impact of e-WOM on the purchase intention of Instagram social network users who have different aged groups.

Table 8: Test the difference between age and purchase intention

\begin{tabular}{|c|c|c|c|c|c|}
\hline \multicolumn{6}{|c|}{ Test of Homogeneity of Variances } \\
\hline \multicolumn{6}{|l|}{ Purchase Intention } \\
\hline Levene Statistic & \multicolumn{2}{|l|}{ df1 } & \multicolumn{2}{|l|}{ df2 } & Sig. \\
\hline 2.804 & & 1 & & 698 & .094 \\
\hline \multicolumn{6}{|c|}{ ANOVA } \\
\hline \multicolumn{6}{|l|}{ Purchase Intention } \\
\hline & Sum of Squares & $\mathrm{df}$ & Mean Square & $\mathrm{F}$ & Sig. \\
\hline Between Groups & .024 & 1 & .024 & .049 & .826 \\
\hline Within Groups & 346.496 & 698 & .496 & & \\
\hline Total & 346.520 & 699 & & & \\
\hline
\end{tabular}


INDEPENDENT JOURNAL OF MANAGEMENT \& PRODUCTION (IJM\&P)

http://www.ijmp.jor.br

v. 12, n. 4, May-June 2021

ISSN: 2236-269X

DOI: $10.14807 /$ ijmp.v12i4.1336

The result of the Test of Homogeneity of Variances has Sig. $=.094>0.05$, the variance between the groups did not differ, get standard to analyze ANOVA. The ANOVA test results show that the Sig $=0.826>0.05$, the hypothesis $(\mathrm{H} 6)$ is accepted.

\subsubsection{Income}

- H7: There is no difference in the impact of e-WOM on the purchase intention of Instagram social network users who have different incomes.

Table 9: Test the difference between income and purchase intention

\begin{tabular}{|c|c|c|c|c|c|}
\hline \multicolumn{6}{|c|}{ Test of Homogeneity of Variances } \\
\hline \multicolumn{6}{|l|}{ Purchase Intention } \\
\hline Levene Statistic & \multicolumn{2}{|l|}{ df1 } & \multicolumn{2}{|l|}{ df2 } & Sig. \\
\hline .743 & & 2 & & 697 & .476 \\
\hline \multicolumn{6}{|c|}{ ANOVA } \\
\hline \multicolumn{6}{|l|}{ Purchase Intention } \\
\hline & Sum of Squares & $\mathrm{df}$ & Mean Square & $\mathrm{F}$ & Sig. \\
\hline Between Groups & .208 & 2 & .104 & .210 & .811 \\
\hline Within Groups & 346.312 & 697 & .497 & & \\
\hline Total & 346.520 & 699 & & & \\
\hline
\end{tabular}

Similar to the result of the age group, this result of the Test of Homogeneity of Variances has Sig. $=.476>0.05$, get standard analyze ANOVA. The ANOVA result indicates Sig $=0.811>0.05$; the hypothesis (H7) is accepted.

In summary, the impact of e-WOM on purchase intention is different in gender, but it has no difference between the aged group and income.

\section{CONCLUSION}

Based on data collected from 700 respondents, the research result confirmed the positive effect of eWOM on purchasing intent, consistent with the studies presented by Park et al. (2007), Lin et al. (2013) and Lim (2016). The analysis results show that all four elements of e-WOM influence the users' buying intent on Instagram, in which the impact decreasing level is as follows: information provider's Expertise, the quantity of e-WOM, source credibility of eWOM, and the quality of e-WOM.

Notably, in the author's study, the Information Provider's Expertise scale has the most significance to the purchasing intent on INSTAGRAM of the user. This result gets similar to that of Lim (2016). Besides, the study found that there was a difference in the impact of eWOM on Instagram User's buying intent by gender, but it did not differ between age groups and income.

From the results of the empirical research, the author found that to increase customer purchase intent, the use of e-WOM is a viable option that businesses may be interested in 
DOI: 10.14807/ijmp.v12i4.1336

considering. Collaboration with influencers and businesses is also seen as a useful way to help businesses inform about products, convey messages, and reach more naturally to consumers. In particular, the quality of e-WOM has the most substantial impact level among the e-WOM factors in the study. In parallel with the quality, businesses also need to improve both the quantity of e-WOM as well as provide reliable e-WOM sources to create a level of trust with customers. If doing so, businesses will influence the purchasing intent of Instagram users, particularly customers, in general.

The study is expected to help administrators understand the relationship between eWOM and the buying intent of social media users, thereby providing administrators with market solutions, especially and for businesses with limited finances. Accurately, from the analysis results, we see that the focus on conveying messages through the online environment is an indispensable trend that all businesses must pay attention to and implement. In particular, the most important is the Experience and Expertise of the information provided is extremely important in affecting customers' purchase intentions.

Also, when an individual has a positive attitude and needs to search for word-of-mouth information on social media, they tend to rate this eWOM information as useful, and thus the ability to Information acceptance is higher. Finally, when users and applications accept referral information on social networks, they will have a higher intention to purchase, even introduce products/services to friends. On the other hand, businesses need to make it possible for customers to experience their opinions and opinions.

However, in order for these ideas to be positive for customers to have a good experience, the best way is that the business needs to be done right from the beginning, i.e., providing quality products and customer service excellent goods. Besides, if the business uses celebrities to promote or introduce products, selecting objects with Expertise in the field of business is necessary and mandatory. Particularly for individuals that they own or are perceived by the community as power, knowledge, status, and many followers on social platforms, namely Instagram, they are called the influencer.

\section{REFERENCES}

Anderson, J. C., \& Gerbing, D. W. (1988). Structural equation modeling in practice: A review and recommended two-step approach. Psychological Bulletin, 103(3), 411-423.

Awad, N. F., \&Ragowsky, A. (2008). Establishing Trust in Electronic Commerce Through Online Word of Mouth: An Examination Across Genders. Journal of Management Information Systems, 24(4), 101-121. 
Bhattacherjee, A., \& Sanford, C. (2006). Influence processes for information technology acceptance: An elaboration likelihood model. MIS Quarterly, 30(4), 805-825.

Bickart, B., \& Schindler, R. M. (2001). Internet forums as influential sources of consumer information. Journal of Interactive Marketing, 15(3), 31-40.

Bloch, P. H., \& Richins, M. L. (1986). A Theoretical Model for the Study of Product Importance Perception. Journal of Consumer Research, 47, 69-81.

Cakim, I. M. (2009). Implementing Word of Mouth Marketing: Online Strategies to Identify Influencers, Craft Stories, and Draw Customers, John Wiley \& Sons.

Chatterjee, P. (2001). Online Reviews: Do Consumers Use Them?. Advances in Consumer Research, 28(1), 129-134.

Chaiken, S. (1980). Heuristic versus systematic information processing and the use of source versus message cues in persuasion. Journal of Personality and Social Psychology, 39(5), 752-66.

Chen, Y., \& Xie, J. (2004). Online consumer review: A new element of marketing communications mix. Working Paper. University of Arizona.

Cheung, C. M. K., \& Thadani, D. R. (2012). The impact of electronic word-of-mouth communication: A literature analysis and integrative model. Decision Support Systems, 54(1), 461-470.

Cheung, C. M. K., Lee, M. K. O., \& Rabjohn, N. (2008). The impact of electronic word-ofmouth, Internet Research, 18(3), 229-247.

doi:10.1108/10662240810883290

Clement, J. (2019). Number of monthly active Instagram users 2013-2018.

https://www.statista.com/statistics/253577/number-of-monthly-active-instagramusers/?id=5601\&resource_name=eBookBrandAmbassadorProgram\&resource_type=Guide/ (Accessed 03 December 2019).

DeLone, W. H., \& McLean, E. R. (1992). Information Systems Success: The Quest for the Dependent Variable. Information Systems Research, 3(1), 60-95.

Erkan, I. (2016). The Influence of Electronic Word of Mouth in Social Media on Consumer' Purchase Intention. Retrieved from https://bura.brunel.ac.uk/bitstream/2438/12972/1/FulltextThesis.pdf.

Filieri, R., \& McLeay, F. (2014). E-WOM and Accommodation: An Analysis of the Factors That Influence Travelers' Adoption of Information from Online Reviews. Journal of Travel Research, 53(1), 44-57.

Gilly, M. C., Graham, J. L., Wolfinbarger, M. F., \& Yale, L. J. (1998). A dyadic study of interpersonal information search. Journal of Academy of Marketing Science, 26(2),83-100.

Goldenberg, J., Libai, B., \& Muller, E. (2001). Talk of the Network: A Complex Systems Look at the Underlying Process of Word-of-Mouth. Marketing Letters, 12(3), 211-223.

Hair, J. F., Tatham, R. L., Anderson, R. E., \& Black, W. (1998). Multivariate Data Analysis, 5th ed. Pearson: New York.

Hennig-Thurau, T., Gwinner, K. P., Walsh, G., \& Gremler, D. D. (2004). Electronic word-ofmouth via consumer-opinion platforms: What motivates consumers to articulate themselves on the Internet?. Journal of Interactive Marketing, 18(1), 38-52. 
Holvland, C. I., \& Weiss, W. (1951). The Influence of Source Credibility on Communication Effectiveness, Public Opinion Quarterly, 15, 635-650.

Huang, M., Cai, F., Tsang, A. S. L., \& Zhou, N. (2011). Making your online voice loud: the critical role of WOM information. European Journal of Marketing, 45(7-8), 1277-1297.

Kalwani, M. U., \& Silk, A. J. (1982). On the reliability and predictive validity of purchase intention measures. Marketing Science, 1(3), 243-286.

Kemp, S. (2019). Digital 2019: Vietnam. https://datareportal.com/reports/digital-2019vietnam/ (Accessed 31 January 2019).

Knightley, E. (2018). 20 Influencer Marketing Statistics that Will Surprise You.

Retrieved from https://digitalmarketinginstitute.com/blog/20-influencer-marketing-statisticsthat-will-surprise-you.

Lee, E.-J., \& Shin, S. Y. (2014). When do consumers buy online product reviews? Effects of review quality, product type, and reviewer's photo. Computers in Human Behavior, 31(1), 356-366.

Lim, L. M. J. (2016). Analyzing the impact of electronic word of mouth on purchase intention and willingness to pay for tourism related products. Retrieved from http://www.apbersociety.org/Asia_Pacific_Business_and_Economics_Research_Society/Jour nal_files/LLim2016.pdf.

Lin, C., Wu, Y-S., \& Chen, J-C. V. (2013). Electronic word-of-mouth: the moderating roles of product involvement and brand image. Proceedings of 2013 International Conference on Technology Innovation and Industrial Management. 29-31.

Litvin, S. W., Goldsmith, R. E., \& Pan, B. (2008). Electronic word-of-mouth in hospitality and tourism management. Tour Manage, 29, 458-468. DOI:

10.1016/j.tourman.2007.05.011.

Liu, Y. (2006). Word of Mouth for Movies: Its Dynamics and Impact on Box Office Revenue. Journal of Marketing, 70(3), 74-89.

Moran, G., \& Muzellec, L. (2014). eWOM credibility on social networking sites: A framework. Journal of Marketing Communications, (ahead-of-print)), 1-13.

Nielsen. (2012). State of the Media: The Social Media Report. Available at: http://www.nielsen.com/content/dam/corporate/us/en/reports-downloads/2012-Reports/TheSocial-Media-Report-2012.pdf.

Nunnally, J. C., \& Bernstein, I. H. (1994). The Assessment of Reliability. Psychometric Theory, 3, 248-292.

Park, D., Lee, J., \& Ham, I. (2007). The effect of on-line consumer reviews on consumer purchasing intention: The moderating role of involvement. International Journal of Electronic Commerce, 11(4), 125-148.

Petty, R. E., \& Cacioppo, J. T. (1986). Communication and Persuasion: Central and Peripheral Routes to Attitude Change, Springer-Verlag: New York.

Pitta, D. A., \& Fowler, D. (2005). Online consumer communities and their value to new product developers. Journal of Product \& Brand Management, 14(5), 283-291.

Prendergast, G., Ko, D., \& Yuen, S. Y. V. (2010). Online word of mouth and consumer purchase intentions. International Journal of Advertising, 29(5), 687-708. 
DOI: 10.14807/ijmp.v12i4.1336

Sussman, S. W., \& Siegal, W. S. (2003). Informational influence in organizations: An integrated approach to knowledge adoption. Information Systems Research, 14(1), 47-65.

Tabachnick, B. G., \& Fidell, L. S. (1996). Using Multivariate Statistics, 3rd ed, Harper Collins: New York.

Thomas, G. M. (2004). Building the buzz in the hive mind. Journal of Consumer Behaviour, 4(1), 64-72.

Wang, X., Yu, C., \& Wei, Y. (2012). Social Media Peer Communication and Impacts on Purchase Intentions: A Consumer Socialization Framework. Journal of Interactive Marketing, 26(4), 198-208.

100 Social Media Statistics For Marketers in 2020 +. [online] https://statusbrew.com/insights/social-media-statistics-2020/ (Accessed 19 November 2019) 